\title{
Halopenitus persicus gen. nov., sp. nov., an archaeon from an inland salt lake
}

\author{
Mohammad Ali Amoozegar, ${ }^{1,2}$ Ali Makhdoumi-Kakhki, ${ }^{1,2}$ \\ Seyed Abolhassan Shahzadeh Fazeli, ${ }^{2,3}$ Reza Azarbaijani ${ }^{2}$ \\ and Antonio Ventosa ${ }^{4}$
}

Correspondence

Mohammad Ali Amoozegar amoozegar@ibrc.ir or amozegar@khayam.ut.ac.ir

\author{
${ }^{1}$ Extremophile Laboratory, Department of Microbiology, School of Biology, College of Science, \\ University of Tehran, Tehran, Iran \\ ${ }^{2}$ Microorganisms Bank, Iranian Biological Resource Centre (IBRC), ACECR Tehran, Iran \\ ${ }^{3}$ Department of Genetics, Royan Institute for Reproductive Biomedicine, ACECR, Tehran, Iran \\ ${ }^{4}$ Department of Microbiology and Parasitology, Faculty of Pharmacy, University of Sevilla, Sevilla, \\ Spain
}

\begin{abstract}
A novel pale pink-pigmented halophilic archaeon, strain $\mathrm{DC}^{\top} \mathrm{O}^{\top}$, was isolated from Aran-Bidgol salt lake, a hypersaline playa in Iran. Cells of strain $\mathrm{DC}^{\top} 0^{\top}$ were non-motile and pleomorphic, from rods to triangular or disc-shaped. Strain $\mathrm{DC} 30^{\top}$ required at least $1.7 \mathrm{M} \mathrm{NaCl}$ and $0.05 \mathrm{M} \mathrm{MgCl}_{2}$ for growth (optimum, $3 \mathrm{M} \mathrm{NaCl}$ and $0.1 \mathrm{M} \mathrm{MgCl}_{2}$ ). The optimum $\mathrm{pH}$ and temperature for growth of strain $\mathrm{DC}^{\top} \mathrm{O}^{\top}$ were $\mathrm{pH} 7.5$ and $40{ }^{\circ} \mathrm{C}$, respectively, although it was capable of growth over $\mathrm{pH}$ and temperature ranges of $6.5-8.5$ and $25-50{ }^{\circ} \mathrm{C}$, respectively. Analysis of the 16S rRNA gene sequence showed that strain $\mathrm{DC}^{\top} 0^{\top}$ was a member of the family Halobacteriaceae. However, it had low $16 \mathrm{~S}$ rRNA gene sequence similarities of $92.4 \%, 89.4 \%$ and $89.1 \%$ to the most closely related haloarchaeal taxa, the type species of the genera Halorubrum, Halogranum and Haloplanus, respectively. The DNA G + C content was 66.0 mol\%. Phosphatidylglycerol and phosphatidylglycerol phosphate methyl ester, common phospholipids found in haloarchaea, were present. Three minor phospholipids and one unidentified glycolipid were also observed. The only quinone present was $\mathrm{MK}-8\left(\mathrm{II}-\mathrm{H}_{2}\right)$. The physiological, biochemical and phylogenetic differences between strain $\mathrm{DC} 30^{\top}$ and other previously described genera of extremely halophilic archaea suggest that strain $\mathrm{DC} 0^{\top}$ represents a novel species in a new genus within the family Halobacteriaceae, for which the name Halopenitus persicus gen. nov., sp. nov. is proposed. The type strain of Halopenitus persicus is DC $30^{\top}\left(=\operatorname{IBRC} 10041^{\top}=\mathrm{KCTC}^{\top} 4046^{\top}\right)$.
\end{abstract}

The red-pink colour is a common feature of hypersaline aquatic environments and is due to the very high cell densities $\left(\geqslant 10^{7}\right.$ cells $\mathrm{ml}^{-1}$ ) of extremely halophilic microorganisms of the family Halobacteriaceae that impart a red colour (Oren, 2002). Other red-pigmented bacteria, such as species of the genus Salinibacter, may also be present, but are usually less abundant than haloarchaea (Antón et al., 2008). The family Halobacteriaceae (order Halobacteriales, class Halobacteria, domain Archaea) includes aerobic microorganisms which need at least $1.5 \mathrm{M} \mathrm{NaCl}$ for growth (Grant et al., 2001). Except for some members of the genus

Abbreviations: MGM, modified growth medium; PGS, phosphatidylglycerol sulfate.

The GenBank/EMBL/DDBJ accession number for the 16S rRNA gene sequence of strain $\mathrm{DC}^{\top}{ }^{\top}$ is JF979130.

Three supplementary figures are available with the online version of this paper.
Natrialba, which are non-pigmented, all members of the family Halobacteriaceae are pink to red-pigmented due to the presence of carotenoids (Kamekura \& Dyall-Smith, 1995; Hezayen et al., 2001; Grant et al., 2001). In this study, we describe a pale pink-pigmented, extremely halophilic archaeon isolated from Lake Aran-Bidgol, an inland hypersaline playa in Iran, and we propose that it represents a novel species in a new genus within the family Halobacteriaceae.

Strain DC $30^{\mathrm{T}}$ was isolated from a brine sample collected in November 2007 from the saline Lake Aran-Bidgol (34 $26^{\prime} \mathrm{N}$, $51^{\circ} 48^{\prime} \mathrm{E}$ ). The water of the lake had a temperature of $38^{\circ} \mathrm{C}$ at the time of sampling, a pH of 7.1 and a salinity of $31 \%$. This playa can be considered as thalassohaline, with $\mathrm{NaCl}$ as the major salt. For strain isolation, modified growth medium (MGM) was used with $23 \%$ total salt concentration, as described in the Halohandbook (Dyall-Smith, 2006). This medium contained a $23 \%$ salt mixture, prepared from a $30 \%$ stock solution, consisting of $\left(1^{-1}\right): 240 \mathrm{~g}$ 
$\mathrm{NaCl}, 35 \mathrm{~g} \mathrm{MgSO}_{4} .7 \mathrm{H}_{2} \mathrm{O}, 30 \mathrm{~g} \mathrm{MgCl}_{2} \cdot 6 \mathrm{H}_{2} \mathrm{O}, 7 \mathrm{~g} \mathrm{KCl}$ and $1 \mathrm{~g} \mathrm{CaCl} \cdot 2 \mathrm{H}_{2} \mathrm{O}$, supplemented with $1 \%(\mathrm{w} / \mathrm{v})$ peptone (Merck) and $0.2 \%(\mathrm{w} / \mathrm{v})$ yeast extract (Merck); $1.5 \%(\mathrm{w} / \mathrm{v})$ agar was used for solidified media if necessary. The $\mathrm{pH}$ of the medium was adjusted to 7.2-7.4 with $2 \mathrm{M}$ Tris-base (Merck). Brine samples were cultured in $23 \%$ MGM solid medium after preparing the appropriate dilutions at the laboratory. Inoculated plates were incubated at $40{ }^{\circ} \mathrm{C}$ for up to two months. After successive cultivation, a pure isolate designated strain $\mathrm{DC} 30^{\mathrm{T}}$ was obtained. The characterization of this strain was achieved by following the minimal standards recommended by Oren et al. (1997) for describing novel taxa of the order Halobacteriales. The type strains Haloferax volcanii DSM $3754^{\mathrm{T}}$ and Halorubrum saccharovorum DSM $1137^{\mathrm{T}}$ were used as reference strains in positive and negative testing.

The genomic DNA of strain $\mathrm{DC} 30^{\mathrm{T}}$ was extracted as described by Lam in section 4.2.2 of the Halohandbook version 7 (Dyall-Smith, 2006) and the 16S rRNA gene was amplified using the archaeal universal primers: $21 \mathrm{~F}$ (DeLong, 1992) and 1492R (Lane et al., 1985). PCR products were purified with the DNA purification kit (Roche) according to the manufacturer's instructions, and electrophoresed on a $1 \%$ agarose gel to check quality. Ligation of the PCR products with the pGEM-T vector, transformation of Escherichia coli $\mathrm{DH} 5 \alpha$, and selection of the transformants were carried out with a pGEM-T TA cloning kit (Promega) according to the manufacturer's instructions. Multiple clones were randomly selected and then sequenced by Macrogen (South Korea) to determine whether the strain possessed multiple distinct 16S rRNA gene sequences. Phylogenetic analysis was performed using the software package MEGA version 4 (Tamura et al., 2004) after obtaining multiple alignments of data available from public databases using CLUSTAL_X (Thompson et al., 1997). Clustering was performed using the neighbour-joining (Saitou \& Nei, 1987), maximum-parsimony (Fitch, 1971) and minimum-evolution (Rzhetsky \& Nei, 1992) methods. Bootstrap analysis was used to evaluate the tree topology of the neighbour-joining data by performing 1000 resamplings (Felsenstein, 1985).

Ten almost complete 16S rRNA gene sequences (1440 nt) of strain DC $30^{\mathrm{T}}$ were obtained. Sequence comparisons indicated that they had identical sequences. The $16 \mathrm{~S}$ rRNA gene sequence analysis showed that strain $\mathrm{DC} 30^{\mathrm{T}}$ was a member of the family Halobacteriaceae, but there were low $16 \mathrm{~S}$ rRNA gene sequence similarities to type strains of other members of this family. The closely related haloarchaeal taxa were: Halorubrum luteum CGSA15 $^{\mathrm{T}}$ (93.1\% 16S rRNA gene sequence similarity), Halogranum amylolyticum TNN $58^{\mathrm{T}}$ $(89.4 \%)$ and Haloplanus vescus $\mathrm{RO} 5-8^{\mathrm{T}}$ (89.1\%); while the $16 \mathrm{~S}$ rRNA gene sequence similarity with the type species of the genera Halorubrum, Halogranum and Haloplanus was $92.4 \%, 88.7 \%$ and $88.1 \%$, respectively. Phylogenetic analysis using the neighbour-joining algorithm revealed that strain DC $30^{\mathrm{T}}$ was in a separate clade to these genera (Fig. 1). The phylogenetic position was also confirmed by trees generated using the minimum-evolution and maximumparsimony algorithms (see Figs S1 and S2, available in IJSEM Online).

Cell morphology and motility were examined using a microscope (BX41; Olympus) equipped with phase-contrast optics. For photography, drops of exponentially growing liquid cultures were used directly without fixing. Colony morphology was observed on agar medium under optimal growth conditions after incubation at $40{ }^{\circ} \mathrm{C}$ for 14 days. The Gram reaction was determined by following the method outlined by Dussault (1955). Strain DC $30^{\mathrm{T}}$ was non-motile, pleomorphic, from rods to triangular or discshaped, and stained Gram-negative. Colonies on agar plates were small (approximately $1.0 \mathrm{~mm}$ diameter), convex, round, with an entire edge and pale pink-pigmented.

Physiological tests were conducted using liquid or solid (1.5\% agar) MGM as mentioned above, unless stated otherwise. Liquid cultures were incubated at $40{ }^{\circ} \mathrm{C}$ on a shaking incubator at 200 r.p.m. Growth rates were determined by monitoring the increase in $\mathrm{OD}_{600}$. Growth temperature range was examined in liquid $\mathrm{MGM}$ at temperatures from $20{ }^{\circ} \mathrm{C}$ to $55{ }^{\circ} \mathrm{C}$ with $5{ }^{\circ} \mathrm{C}$ intervals. For growth experiments at different $\mathrm{pH}$ values a range of 5.0-9.0 was tested; the buffers MES (pH 5-6.5), HEPES ( $\mathrm{pH} 7-8$ ) and CHES ( $\mathrm{pH}$ 8.5-9) were added at a concentration of $50 \mathrm{mM}$. The requirements for $\mathrm{NaCl}$ and $\mathrm{MgCl}_{2}$ for growth were determined in media containing $0-5 \mathrm{M} \mathrm{NaCl}$ (in $0.5 \mathrm{M}$ increments) or $0-1 \mathrm{M} \mathrm{MgCl}_{2}$ (in $0.05 \mathrm{M}$ increments), respectively.

Strain DC $30^{\mathrm{T}}$ grew over a temperature range of $25-50{ }^{\circ} \mathrm{C}$ (optimum, $40{ }^{\circ} \mathrm{C}$ ) and a $\mathrm{pH}$ range of 6.5-8.5 (optimum, $\mathrm{pH}$ 7.5). Routine cultivation was conducted at $40{ }^{\circ} \mathrm{C}$ and $\mathrm{pH}$ 7.5. Strain $\mathrm{DC} 30^{\mathrm{T}}$ was capable of growing over a wide range of $\mathrm{NaCl}$ concentrations, from $1.7 \mathrm{M}(10 \%)$ to $4.3 \mathrm{M}$ (25\%) [optimum, $3.0 \mathrm{M}(17 \%)$ ]. At least $0.05 \mathrm{M} \mathrm{MgCl}_{2}$ was required for growth (optimum, $0.1 \mathrm{M} \mathrm{MgCl}_{2}$ ).

Acid production from carbohydrates was tested in unbuffered MGM and was determined by measuring the initial and final $\mathrm{pH}$ of the medium. The culture was considered positive for acid production if the $\mathrm{pH}$ decreased by at least $1 \mathrm{pH}$ unit. To test for carbon source utilization, peptone was omitted from MGM and yeast extract concentration was reduced to $0.1 \mathrm{~g} \mathrm{l}^{-1}$ (Oren et al., 1997). The ability of strain $\mathrm{DC} 30^{\mathrm{T}}$ to grow anaerobically in the presence of DMSO $\left(5.0 \mathrm{~g} \mathrm{l}^{-1}\right)$ and to ferment arginine $\left(5.0 \mathrm{~g} \mathrm{l}^{-1}\right)$ was tested in MGM prepared anaerobically in serum tubes according to the procedures described by Bryant (1972) and Balch \& Wolfe (1976). Growth and gas formation with nitrate as the electron acceptor were tested in $10 \mathrm{ml}$ stoppered tubes, completely filled with liquid growth medium to which $\mathrm{NaNO}_{3}$ $\left(5 \mathrm{~g} \mathrm{l}^{-1}\right)$ had been added, and containing an inverted Durham tube (Oren et al., 1997). Tween hydrolysis activity was detected as described by Gutiérrez \& González (1972). Casein, gelatin and starch hydrolysis were determined as described by Oren et al. (1997). Tests for catalase and 


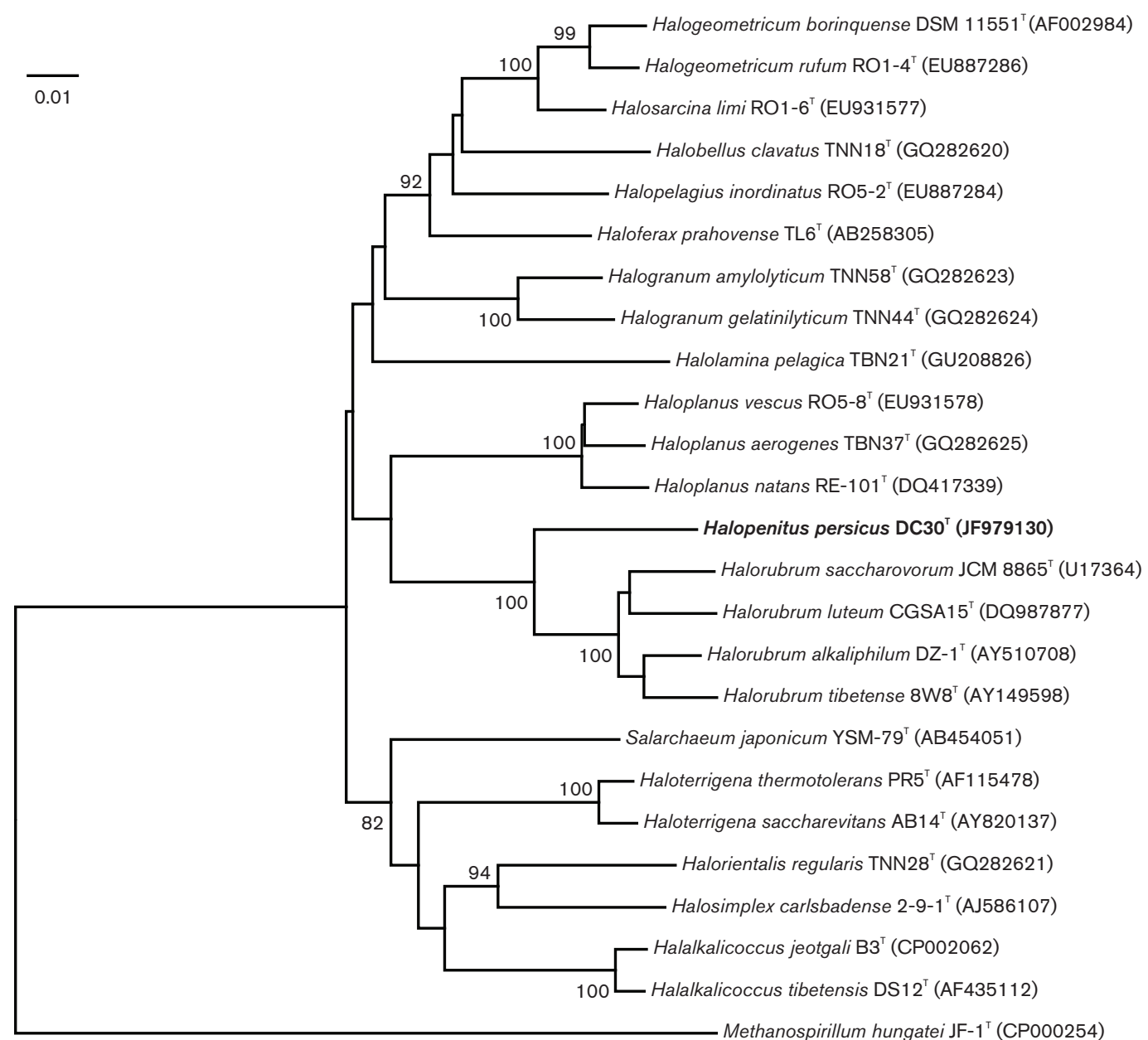

Fig. 1. Neighbour-joining phylogenetic tree based on 16S rRNA gene sequences showing the relationship between strain $\mathrm{DC}^{\top} \mathrm{O}^{\top}$ and its close relatives within the family Halobacteriaceae. GenBank accession numbers are given in parentheses. The sequence of the methanogenic archaeon Methanospirillum hungatei JF-1 ${ }^{\top}$ was used as an outgroup. Bootstrap values (\%) are based on 1000 replicates. Only values $>70 \%$ are shown. Bar, 0.01 substitutions per nucleotide position.

oxidase activities were performed as described by González et al. (1978). Production of $\mathrm{H}_{2} \mathrm{~S}$ was tested by growing strain $\mathrm{DC} 30^{\mathrm{T}}$ in liquid MGM supplemented with $0.5 \%(\mathrm{w} / \mathrm{v})$ $\mathrm{Na}_{2} \mathrm{~S}_{2} \mathrm{O}_{3}$ (Oren et al., 1997). Tryptone water medium supplemented with $23 \%$ total salts was used to test indole production (Smibert \& Krieg, 1994). Susceptibility to antimicrobials was determined by the disc diffusion method after spreading the strain on solid MGM (Oren et al., 1997).

Strain DC $30^{\mathrm{T}}$ was catalase- and oxidase-positive. It could hydrolyse DNA, Tweens 20 and 40, but not Tweens 60 and 80 , casein, gelatin or starch. Strain $\mathrm{DC}^{\mathrm{T}}{ }^{\mathrm{T}}$ utilized $\mathrm{D}$ fructose, D-galactose, D-glucose and maltose. Acid was produced from D-glucose and maltose, but not from Dgalactose, sucrose, D-fructose, D-xylose, D-ribose, D-mannitol, D-mannose, trehalose, L-arabinose or lactose. The detailed physiological and biochemical characteristics of strain $\mathrm{DC} 30^{\mathrm{T}}$ are listed in Table 1 and in the genus and species descriptions.
The DNA G $+\mathrm{C}$ content of strain $\mathrm{DC} 30^{\mathrm{T}}$ was determined by the HPLC method (Mesbah et al., 1989) and was $66.0 \mathrm{~mol} \%$, which is within the range described for the family Halobacteriaceae (Grant et al., 2001). This value is similar to that reported for the genus Haloplanus but very different from those of the genera Halorubrum and Halogranum (Table 1).

Polar lipid composition and respiratory quinones were determined by the services of the DSMZ and Dr Brian Tindall (Braunschweig, Germany). Polar lipids were separated by $2 \mathrm{D}$ silica gel TLC. Methods, including the solvents in each direction and detection reagents, were described by Hezayen et al. (2001). Phosphatidylglycerol and phosphatidylglycerol phosphate methyl ester were present but phosphatidylglycerol sulfate (PGS) was not observed. One unidentified glycolipid and three minor phospholipids were also observed (Fig. S3). The absence of PGS in this novel archaeon differentiates this taxon from phylogenetically 
Table 1. Differential characteristics between strain $\mathrm{DC} 30^{\top}$ and closely related genera within the order Halobacteriales

Taxa: 1, DC $30^{\mathrm{T}}$; 2, Halorubrum; 3, Halogranum; 4, Haloplanus; 5, Halobellus; 6, Halobacterium. Data are from this study and the type species of the genus Halorubrum (Halorubrum saccharovorum; Grant et al., 2001); Halogranum (Halogranum rubrum; Cui et al., 2010); Haloplanus (Haloplanus natans; Bardavid et al., 2007); Halobellus (Halobellus clavatus; Cui et al., 2011) and Halobacterium (Halobacterium salinarum; Grant et al., 2001). +, Positive; -, negative; ND, no data available.

\begin{tabular}{|c|c|c|c|c|c|c|}
\hline Characteristic & 1 & 2 & 3 & 4 & 5 & 6 \\
\hline Cell size $(\mu \mathrm{m})$ & $0.6-1.5 \times 4.9-8.7$ & $0.6-1.2 \times 2.5$ & $1.0-2.0$ & $2.5-8.0$ & $0.5-1.0 \times 1.0-6.0$ & $0.5-1.0 \times 1.0-6.0$ \\
\hline Pigmentation & Pale pink & Orange-red & Red & Pink & Red & Red \\
\hline Optimum $\mathrm{NaCl}(\mathrm{M})$ & 3.0 & $2.5-4.5$ & 3.9 & 3.0 & 2.6 & $3.4-4.3$ \\
\hline $\mathrm{Mg}^{2+}$ requirement & + & + & + & + & - & + \\
\hline Optimum temperature $\left({ }^{\circ} \mathrm{C}\right)$ & 40 & 50 & 37 & 40 & 37 & 50 \\
\hline $\mathrm{H}_{2} \mathrm{~S}$ production & - & + & + & ND & - & + \\
\hline Reduction of nitrate to nitrite & - & - & - & + & + & + \\
\hline Production of acid from D-glucose & + & + & + & - & + & - \\
\hline Hydrolysis of gelatin & - & - & + & - & - & + \\
\hline Indole production & - & - & - & + & + & + \\
\hline
\end{tabular}

related members of the family Halobacteriaceae: Halorubrum, Haloplanus and Halobellus, which contain PGS (Grant et al., 2001; Bardavid et al., 2007; Cui et al., 2011). Furthermore, the minor phospholipids associated with strain $\mathrm{DC} 30^{\mathrm{T}}$ were not detected in the genus Halogranum, another closely phylogenetically related taxon (Cui et al., 2010). Respiratory lipoquinones were determined as described by Wainø et al. (2000). MK-8(II- $\left.\mathrm{H}_{2}\right)$ was the only respiratory lipoquinone present in strain DC $30^{\mathrm{T}}$.

In conclusion, the results of the morphological and physiological properties of the novel isolate, the low $16 \mathrm{~S}$ rRNA gene sequence similarities with other genera of the family Halobacteriaceae and the distinctive components of the polar lipid profile suggest that strain $\mathrm{DC}^{\mathrm{T}} \mathrm{T}^{\mathrm{T}}$ represents a novel species of a new genus in the family Halobacteriaceae, for which the name Halopenitus persicus gen. nov., sp. nov. is proposed.

\section{Description of Halopenitus gen. nov.}

Halopenitus (Ha.lo.pe'ni.tus. Gr. n. hals halos salt; L. masc. adj. penitus inner, interior; N.L. masc. n. Halopenitus intended to mean an archaeon isolated from an inland salt lake).

Cells are non-motile and pleomorphic, from rods to triangular or disc-shaped. Gram-staining-negative. Colonies are pale pink-pigmented. Strictly aerobic; oxygen is used as the terminal electron acceptor. Growth occurs at $\mathrm{pH}$ 6.58.5 , at $25-50{ }^{\circ} \mathrm{C}$ and at $1.7-4.3 \mathrm{M}(10-25 \%) \mathrm{NaCl}$. At least $0.05 \mathrm{M} \mathrm{MgCl}_{2}$ is required for growth. Optimal growth occurs at $\mathrm{pH} 7.5,40{ }^{\circ} \mathrm{C}, 3.0 \mathrm{M}(17 \%) \mathrm{NaCl}$ and $0.1 \mathrm{M}$
$\mathrm{MgCl}_{2}$. Extremely halophilic. Polar lipids include phosphatidylglycerol, phosphatidylglycerol phosphate methyl ester, one unidentified glycolipid and three minor phospholipids. MK-8 $\left(\mathrm{II}-\mathrm{H}_{2}\right)$ is the only respiratory lipoquinone present. The DNA G + C content of the type strain of the only species in the genus is $66.0 \mathrm{~mol} \%$ (HPLC method). Phylogenetically affiliated to the family Halobacteriaceae. The type species is Halopenitus persicus. Recommended three-letter abbreviation of the genus: $H p t$.

\section{Description of Halopenitus persicus sp. nov.}

Halopenitus persicus (per'si.cus. L. masc. adj. persicus of Persia, where the type strain was isolated).

Exhibits the following properties in addition to those given in the genus description. Cell size of $0.6-1.5 \times 4.9-8.7 \mu \mathrm{m}$ when grown in liquid MGM under optimum conditions. Colonies are small (approximately $1.0 \mathrm{~mm}$ diameter). Cells lyse in water. Catalase- and oxidase-positive. Does not grow under anaerobic conditions with nitrate, arginine or DMSO. Nitrate reduction to nitrite, and gas formation from nitrate are not observed. Hydrolyses DNA, Tweens 20 and 40 but not Tweens 60 and 80, casein, gelatin or starch. Indole is not produced from tryptophan. Acid is produced from D-glucose and D-maltose, but not from L-arabinose, D-fructose, sucrose, D-mannitol, D-galactose, lactose or Dribose. $\mathrm{H}_{2} \mathrm{~S}$ is not produced from thiosulfate. Does not produce arginine dihydrolase, lysine decarboxylase or ornithine decarboxylase. Methyl red and Voges-Proskauer tests are negative. Utilizes D-fructose, D-galactose, D-glucose, maltose, L-asparagine, L-glycine, L-proline, and L-valine as 
sole sources of carbon and energy, but not L-arabinose, sucrose, D-mannitol, D-ribose, L-arginine, L-methionine, L-aspartic acid, L-cysteine, L-phenylalanine or L-tyrosine. Susceptible to the following antimicrobial compounds $(\mu \mathrm{g}$ per disc unless otherwise stated): anisomycin (35), bacitracin (10 U), nitrofurantoin (300) and novobiocin (5). Resistant to amoxicillin (25), ampicillin (10), cephalotin (30), carbenicillin (100), cefoxitin (30), chloramphenicol (30), erythromycin (5), gentamicin (10), kanamycin (5), nalidixic acid (30), neomycin (30), penicillin G (10 U), polymyxin B (100 U), rifampicin (5), streptomycin (10), tetracycline (30) and tobramycin (10).

The type strain is DC $30^{\mathrm{T}}\left(=\mathrm{IBRC} 10041^{\mathrm{T}}=\mathrm{KCTC} 4046^{\mathrm{T}}\right)$, and was isolated from Aran-Bidgol salt lake, Iran. The DNA G $+C$ content of the type strain is $66.0 \mathrm{~mol} \%$ (HPLC).

\section{Acknowledgements}

This work was supported by grants from Iranian Biological Resource Center (IBRC) (MI-1388-01) and International Foundation for Science (IFS) (A/4527-1).

\section{References}

Antón, J., Peña, A., Santos, F., Martínez-García, M., Schmitt-Kopplin, P. \& Rosselló-Mora, R. (2008). Distribution, abundance and diversity of the extremely halophilic bacterium Salinibacter ruber. Saline Syst 4, 15.

Balch, W. E. \& Wolfe, R. S. (1976). New approach to the cultivation of methanogenic bacteria: 2-mercaptoethanesulfonic acid (HS-CoM)dependent growth of Methanobacterium ruminantium in a pressureized atmosphere. Appl Environ Microbiol 32, 781-791.

Bardavid, R. E., Mana, L. \& Oren, A. (2007). Haloplanus natans gen. nov., sp. nov., an extremely halophilic, gas-vacuolate archaeon isolated from Dead Sea-Red Sea water mixtures in experimental outdoor ponds. Int J Syst Evol Microbiol 57, 780-783.

Bryant, M. P. (1972). Commentary on the Hungate technique for culture of anaerobic bacteria. Am J Clin Nutr 25, 1324-1328.

Cui, H. L., Gao, X., Sun, F. F., Dong, Y., Xu, X. W., Zhou, Y. G., Liu, H. C., Oren, A. \& Zhou, P. J. (2010). Halogranum rubrum gen. nov., sp. nov., a halophilic archaeon isolated from a marine solar saltern. Int $J$ Syst Evol Microbiol 60, 1366-1371.

Cui, H. L., Yang, X., Gao, X. \& Xu, X. W. (2011). Halobellus clavatus gen. nov., sp. nov. and Halorientalis regularis gen. nov., sp. nov., two new members of the family Halobacteriaceae. Int J Syst Evol Microbiol 61, 2682-2689.

DeLong, E. F. (1992). Archaea in coastal marine environments. Proc Natl Acad Sci U S A 89, 5685-5689.

Dussault, H. P. (1955). An improved technique for staining red halophilic bacteria. J Bacteriol 70, 484-485.

Dyall-Smith, M. L. (2006). The Halohandbook: Protocols for Haloarchaeal Genetics. http://www.haloarchaea.com/resources/halohandbook.
Felsenstein, J. (1985). Confidence limits on phylogenies: an approach using the bootstrap. Evolution 39, 783-791.

Fitch, W. M. (1971). Toward defining the course of evolution: minimum change for a specific tree topology. Syst Zool 20, 406-416.

González, C., Gutiérrez, C. \& Ramirez, C. (1978). Halobacterium vallismortis sp. nov. An amylolytic and carbohydrate-metabolizing, extremely halophilic bacterium. Can J Microbiol 24, 710-715.

Grant, W. D., Kamekura, M., McGenity, T. J. \& Ventosa, A. (2001). Order I. Halobacteriales. In Bergey's Manual of Systematic Bacteriology The Archaea and Deeply Branching and Phototrophic Bacteria, 2nd edn, vol. 1, pp. 294-301. Edited by D. R. Boone, R. W. Castenholz \& G. M. Garrity. New York: Springer.

Gutiérrez, C. \& González, C. (1972). Method for simultaneous detection of proteinase and esterase activities in extremely halophilic bacteria. Appl Microbiol 24, 516-517.

Hezayen, F. F., Rehm, B. H. A., Tindall, B. J. \& Steinbüchel, A. (2001). Transfer of Natrialba asiatica B1T to Natrialba taiwanensis sp. nov. and description of Natrialba aegyptiaca sp. nov., a novel extremely halophilic, aerobic, non-pigmented member of the Archaea from Egypt that produces extracellular poly(glutamic acid). Int J Syst Evol Microbiol 51, 1133-1142.

Kamekura, M. \& Dyall-Smith, M. L. (1995). Taxonomy of the family Halobacteriaceae and description of two new genera Halorubrobacterium and Natrialba. J Gen Appl Microbiol 41, 333-350.

Lane, D. J., Pace, B., Olsen, G. J., Stahl, D. A., Sogin, M. L. \& Pace, N. R. (1985). Rapid determination of $16 \mathrm{~S}$ ribosomal RNA sequences for phylogenetic analyses. Proc Natl Acad Sci U S A 82, 6955-6959.

Mesbah, M., Premachandran, U. \& Whitman, W. B. (1989). Precise measurement of the $\mathrm{G}+\mathrm{C}$ content of deoxyribonucleic acid by highperformance liquid chromatography. Int J Syst Bacteriol 39, 159-167.

Oren, A. (2002). Molecular ecology of extremely halophilic Archaea and Bacteria. FEMS Microbiol Ecol 39, 1-7.

Oren, A., Ventosa, A. \& Grant, W. D. (1997). Proposed minimal standards for description of new taxa in the order Halobacteriales. Int J Syst Bacteriol 47, 233-238.

Rzhetsky, A. \& Nei, M. (1992). A simple method for estimating and testing minimum-evolution trees. Mol Biol Evol 9, 945-967.

Saitou, N. \& Nei, M. (1987). The neighbor-joining method: a new method for reconstructing phylogenetic trees. Mol Biol Evol 4, 406425.

Smibert, R. M. \& Krieg, N. R. (1994). Phenotypic characterization. In Methods for General and Molecular Bacteriology, pp. 607-654. Edited by P. Gerhardt, R. G. E. Murray, W. A. Wood \& N. R. Krieg. Washington, DC: American Society for Microbiology.

Tamura, K., Nei, M., Dudley, J. \& Kumar, S. (2004). MEGA4: molecular evolutionary genetics analysis (MEGA) software version 4.0. Mol Biol Evol 24, 1596-1599.

Thompson, J. D., Gibson, T. J., Plewniak, F., Jeanmougin, F. \& Higgins, D. G. (1997). The CLUSTAL_X windows interface: flexible strategies for multiple sequence alignment aided by quality analysis tools. Nucleic Acids Res 25, 4876-4882.

Wainø, M., Tindall, B. J. \& Ingvorsen, K. (2000). Halorhabdus utahensis gen. nov., sp. nov., an aerobic, extremely halophilic member of the Archaea from Great Salt Lake, Utah. Int J Syst Evol Microbiol 50, 183190. 